\title{
Fernão Cardim:
} a epistolografia jesuítica e a construção do outro*

\author{
Eunícia Barros Fernandes ${ }^{* *}$
}

A Narrativa Epistolar de uma Viagem e Missão Jesuítica de Fernão Cardim é fonte para reflexão sobre a escrita de cartas como estratégia da Companhia de Jesus na consolidação de seu "modo de proceder", o que implica nas dimensões devocional e catequética. Argumenta-se que tal estratégia articula a construção da alteridade indígena, definindo uma relação entre a epistolografia jesuítica e o processo colonizador.

Palavras-chave: Jesuítas - Cartas - Alteridade

Fernão Cardim: jesuit letters and the construction of the other

The Epistolary Narrative of a Voyage and a Jesuitical Mission of Fernão Cardim is a source for reflection on the writing of letters as a Jesuit strategy for the consolidation of the "ways of proceeding" of the Company of Jesus - a strategy with both devotional and doctrinal dimensions. Here we argue that such a strategy articulates the construction of the native Other, defining a relation between Jesuit letters and the colonizing process.

Keywords: Jesuits - Letters - Other

\footnotetext{
* Artigo recebido em outubro de 2007 e aprovado para publicação em maio de 2008. Uma versão reduzida deste artigo foi apresentada no $52^{\circ}$ Congresso Internacional de Americanistas, Sevilha/julho de 2006.

** Professora do Departamento de História da PUC/Rio. E-mail: euniciaf@puc-rio.br.
} 


\section{Fernão Cardim: lettres jésuitiques et la construction de l'altérité}

Le Récit Épistolaire d'un Voyage et d'une Mission Jésuitique de Fernão Cardim est source de la réflexion sur l'écriture de lettres comme stratégie de la Société de Jésus pour la consolidation de sa "manière de procéder ", ce qui implique sur les dimensions de la dévotion et de le catéchisme. Il se fait valoir que telle stratégie articule la construction de l'altérité indigène, en définissant une relation entre les lettres jésuitiques et le processus colonisateur.

Mots-clés: Jésuites - Lettres - Altérité

Chegando o padre à terra começaram os flautistas tocar suas flautas com muita festa, o que também fizeram enquanto jantamos debaixo de um arvoredo de aroeira muito altas. Os meninos índios, escondidos em um fresco bosque, cantavam várias cantigas devotas enquanto comemos, que causavam devoção, no meio daqueles matos, principalmente uma pastoril feita de novo para o recebimento do padre visitador seu novo pastor. Chegamos à aldeia à tarde; antes dela um bom quarto de légua, começaram as festas que os índios tinham aparelhadas as quais fizeram em uma rua de altíssimos e frescos arvoredos, dos quais saíam uns cantando e tangendo a seu modo, outros em ciladas saíam com grande grita e urros, que nos atordoavam e faziam estremecer. Os cunumis meninos, com muitos molhos de flechas levantadas para cima, faziam seu motim de guerra e davam sua grita e, pintados de várias cores, nuzinhos, vinham com as mãos levantadas receber a benção do padre, dizendo em português "louvado seja Jesus Cristo". ${ }^{1}$

Lendo ou ouvindo a experiência de Cardim acabamos por criar mentalmente uma imagem. Seja como uma pintura ou uma performance, a cena se realiza dentro de nós a partir das palavras. Vemos arvoredos tomando os caminhos, criando sombras sobre o chão e deixando uma sensação de frescor em tardes quentes baianas. Podemos imaginar que, se olhássemos para cima, veríamos apenas alguns espaços de céu azul de onde viriam os raios que tudo iluminavam. Quase ouvimos a algaravia de sons: o marulhar das árvores pelo vento, os estalos de pés sobre as folhas ou os zunidos graves de rápidos movimentos corporais que se somavam aos cantos, urros e saudações religiosas. Um sorriso involuntário pode nos chegar aos lábios ao nos imaginarmos como aqueles padres que, ao mesmo tempo em que sucumbiam a um encantamento, ${ }^{1}$ Fernão Cardim, "Narrativa epistolar de uma viagem e missão jesuítica", Tratados da terra e gente do Brasil, Belo Horizonte, Itatiaia, 1980, p. 145. 
levavam sustos com o repentino aparecimento de meninos que os cercavam, seguiam, lançavam flechas e saudavam ao Senhor.

Ao criar imagens e nos envolver em suas palavras, Cardim nos faz submergir na vivência alheia como se fosse nossa. As palavras atravessam séculos como, antes, atravessaram espaços, ultrapassaram oceanos e invadiram a vida e a percepção de religiosos ${ }^{2}$ e leigos, ávidos por notícias missionárias. ${ }^{3}$ É sobre tais palavras que vamos refletir sobre como as cartas jesuíticas construíram representações sobre povos e lugares onde se estabeleceram as missões, sobre como formaram visões sobre os domínios coloniais que se constituíam no alvorecer da modernidade; refletir sobre como, mais do que estabelecer visões e percepções, as palavras traçadas definiram parâmetros para a ação daqueles homens, fossem eles religiosos, colonos ou mesmo reis.

Fernão Cardim nasceu na década de 1540, em Viana de Alvito, Portugal, e iniciou noviciado na Companhia de Jesus, em 1566. Já era professo dos quatro votos e ministro do Colégio de Évora, quando foi designado, em 1582, como companheiro do padre visitador Cristóvão de Gouveia, enviado para guiar a missão do Brasil. ${ }^{4}$ A Narrativa Epistolar de uma viagem e missão jesuitica é o relato desta viagem, sendo composta por duas cartas escritas ao Provincial em Portugal. A primeira - sobre a qual me deterei - abarca o período entre a designação de viagem e outubro de 1585 , num extenso comentário sobre a América portuguesa e, de modo particular, sobre os indígenas. A segunda carta, datada de 1590, procura informar os eventos dos anos seguintes, tendo como eixo a viagem de volta a Portugal e o infortúnio de um ataque francês à embarcação. Sobre a segunda não tecerei comentários por fugir ao tema que nos interessa aqui: o encontro com a alteridade índia e a construção de ${ }^{2}$ Adriano Prosperi, em artigo sobre a figura do missionário, destaca exatamente o poder das palavras jesuíticas na ultrapassagem de distâncias através do exemplo de Daniello Bartoli. Orientado por seus superiores, o jesuíta Bartoli escreveu uma História da Companhia de Jesus em 6 volumes (1650 -1673), que abria os horizontes de seus leitores sobre as missões, sem nunca ter saído de seu pequeno quarto. Cf. "The missionary", Baroque personae, University of Chicago Press, 1995 (1'. ed. Italiana em 1991).

${ }^{3}$ Anuncio como avidez o sucesso das publicações das cartas e sua ampla circulação para além dos quadros da Companhia de Jesus. É preciso enfatizar também que a prática epistolar era pensada não apenas como informação, mas também como uma "reunião de todos em um" e como uma "experiência mística", ou seja, pilar para a formação de novos jesuítas. Cf. Alcir Pécora, "Cartas à Segunda Escolástica", in: Adauto Novaes, A outra margem do ocidente, São Paulo, Companhia das Letras, 1999, p. 381.

${ }^{4}$ Os visitadores da Companhia eram responsáveis pela coordenação dos esforços missionários in loco. Instruídos sobre todas as áreas de atuação jesuítica, eram incumbidos de resolverem os dilemas particulares a cada área, organizar os procedimentos, enfim, homogeneizar as atitudes a partir das determinações do Geral. 
uma imagem sobre ela. Observo, por fim, que mais tarde Cardim retornou ao Brasil, tendo sido reitor dos Colégios da Bahia e do Rio de Janeiro, procurador da Província do Brasil em Roma e Provincial.

Recompor rapidamente essa biografia é interessante para inserir suas interpretações em duas chaves. A primeira é a trajetória particular desse missionário, revelando a Narrativa Epistolar como resultado dos primeiros contatos que Cardim viria a estabelecer no Brasil, ou seja, revelando as primeiras impressões do religioso numa relação direta com os indígenas. A segunda é a inclusão de Cardim num quadro mais amplo, onde aparece como um entre inúmeros outros missionários que, no exercício de suas funções, também redigiram cartas que deram forma, sentido e justificativa ao que viviam e ao que encontravam.

A trajetória particular de Cardim nos lembra que a atuação desses jesuítas desdobrava-se em variadas funções, costurando a experiência particular ao desenvolvimento da própria Ordem. Não cabe agora uma reflexão sobre o amadurecimento conexo entre os indivíduos e a Companhia, ${ }^{5}$ mas não posso deixar de assinalar que as atuações posteriores de cada um deles necessariamente dialogavam com o vivido e as referências construídas através dele. Não posso deixar de pensar que, para além da repercussão da Narrativa, da impressão causada em seus primeiros leitores e dos usos que foram feitos dela por terceiros, a pessoa de Cardim carregava consigo essa história, a qual depurava e atualizava através de sua existência e com a qual alimentava outros religiosos atuando como guia, tutor, orientador, confessor, enfim, quando expressava sua devoção e continuava sua missão junto a outros jesuítas.

Por outro lado, lembrar que Cardim é um entre muitos também é chave preciosa, pois nela reside tanto o sentido da escrita das cartas como a possibilidade da construção do outro. Recordar Cardim como parte de uma totalidade nos habilita a perceber articulações para a existência e manutenção da Ordem. Podemos afirmar que a epistolografia era caminho para uma constituição e percepção corporativa, pois através dela se viabilizava conhecimento e controle e se materializava uma prática devocional que singularizava os jesuítas.

A lembrança dessa totalidade nos alerta que os parâmetros que permitiam as compreensões sobre as experiências vividas eram coletivos e que

\footnotetext{
${ }^{5}$ Em especial nesse momento em que há uma multiplicação de Colégios e casas professas: em 1580, existiam cerca de 5.000 jesuítas (cinco vezes mais do que no tempo de Inácio como Geral da Companhia) a dirigir 144 Colégios (113 a mais que em 1556, ano de falecimento de Inácio), além de residências, casas professas e noviciados. Cf. William Bangert (SJ), História da Companhia de Jesus, São Paulo/Porto, Edições Loyola/Apostolado da Imprensa, 1985, p.63.
} 
o estabelecimento de uma dada imagem e/ou visão sobre algo se atrelava necessariamente a sua difusão. Em outras palavras, é pensar que a alteridade constituída numa carta específica era fruto de um intenso diálogo entre os missionários. É imaginar que a Narrativa de Cardim deve ter sido compartilhada entre irmãos, consolidando certas percepções que seriam acionadas quando eles mesmos se defrontassem com indígenas - talvez agindo de modo peculiar entre noviços europeus que jamais haviam viajado -, assim como, anos antes, teriam sido as palavras de outros jesuítas que alimentaram Cardim. Não à toa, as prescrições de Inácio e das Constituições eram de redigir incessantemente.

\section{Escrever}

A prática qualificada pela Companhia se inscrevia num quadro mais amplo, pois a escrita se multiplicara na aurora da modernidade tanto como fruto de dimensões materiais - o desenvolvimento de escolas e universidades e da invenção da prensa por Gutenberg - como de alterações na sensibilidade, na compreensão sobre o ser e o estar no mundo. ${ }^{6}$

A literatura, por exemplo, exibia através de Petrarca uma outra percepção temporal, rompendo com o dualismo medieval que fracionava o tempo em "vida terrena" e "vida eterna". A compreensão tripartida - o Antigo, o Velho e o Novo - dava asas a uma valorização da experiência humana, pois ela era resultado da escolha sobre um determinado passado em detrimento de outro; ou seja, era resultado de uma potencialidade criadora do homem. ${ }^{7}$ Essa valorização humanística definia novos sentidos e convidava os homens a escrever diários, autobiografias, a expor suas ideias e deixar seu registro. Como nos diz Agnes Heller: "o indivíduo renascentista era um indivíduo porque se exteriorizava e, nesse processo de exteriorização, veio a conhecer-se a si próprio e a regozijar-se consigo mesmo". ${ }^{8}$

A exteriorização através da escrita deve ser vista como parte de um amplo "voltar-se para o mundo" vivido naquele momento e com o qual comungava a Companhia de Jesus. Diferentemente das ordens medievais votadas ${ }^{6}$ Ao desenvolver sua reflexão sobre a instituição epistolar jesuítica, José Eisenberg também destaca a transformação em curso. Cf. As missões jesuíticas e o pensamento político moderno, Belo Horizonte, Editora da UFMG, 2000, p. 47.

${ }^{7}$ Berenice Cavalcante, "Ser moderno': a propósito de uma tradição", Revista Semear, n. 4, PUC-Rio, Rio de Janeiro, [1998?]. Disponível em: <http://www.letras.puc-rio.br/catedra/ revista/4Sem_11.html>.

${ }^{8}$ O homem do renascimento, Lisboa, Editorial Presença, 1982, p. 163. 
a um ideal contemplativo, a Companhia propunha imiscuir-se ao mundano para transformá-lo em sagrado. A base de suas ações sedimentava-se numa predisposição missionária que em si mesma deve ser vista como prova de exteriorização, por ir em direção ao outro, implicando numa dimensão social. ${ }^{9}$ A Companhia, assim, estava costurada aos novos tempos: suas práticas representavam um abandono daquelas do passado imediato.

A epistolografia, assim, pode ser compreendida como um elemento da modernidade da Ordem, mesmo sabendo que a redação de cartas não era algo novo no seio da própria Igreja Católica - vide as epístolas de São Paulo dirigidas às primeiras comunidades cristãs - e que a escrita em si estava regrada por tradições formais - ars dictaminis e ars epistolandi - que remetiam a experiências pretéritas de redação. A interpretação de modernidade se assenta tanto no sentido de exteriorização como também na forma e no uso das cartas.

Quanto à forma, destaco as diretrizes definidas por Inácio de Loyola, tais como a redação em línguas modernas - não mais em latim - e sua sistematização, impondo periodicidades e fins atrelados a uma nova experiência e projeto: a atuação dispersa no mundo, especialmente no Novo Mundo. Michel de Certeau auxilia o argumento ao indicar um papel diverso assumido pela escrita:

A descoberta do Novo Mundo, o fracionamento da cristandade, as clivagens sociais que acompanham o nascimento de uma política e de uma razão novas engendram um outro funcionamento da escrita e da palavra. Presa na órbita da sociedade moderna, sua diferenciação adquire uma pertinência epistemológica e social que não tinha antes; em particular, torna-se o instrumento de um duplo trabalho que se refere, por um lado à relação com o homem "selvagem", por outro à relação com a tradição religiosa. Serve para classificar os problemas que o sol nascente do "Novo Mundo" e o crepúsculo da cristandade "medieval" abrem à intelligentsia. ${ }^{10}$

\footnotetext{
9 "A missão é um tipo de abertura significativa que representa a reafirmação de uma vontade de inserção da Igreja em laços diferentes, maiores, profanos, sociais”. Cf. Luiz Felipe Baêta Neves, O combate dos soldados de Cristo na Terra dos Papagaios, Rio de Janeiro, Forense Universitária, 1978, p. 27.

${ }^{10}$ Michel de Certeau, "Etnografia”, A escrita da história, Rio de Janeiro, Forense Universitária, 1985 , p. 213.
} 
Uma nova pertinência, então, articula a escrita como um instrumento classificador e viabilizador de estratégias, ${ }^{11}$ observando que tais estratégias identificam seu uso moderno.

\section{Estratégia individual}

Seguindo Michel de Certeau, podemos nomear estratégia o cálculo realizado para atingir determinada meta, mas é preciso esclarecer o que isso implica. Antes de qualquer coisa, a estratégia exige um sujeito de querer e de poder, pois será ele a estabelecer o cálculo. É preciso também considerar que esse sujeito constitui para si um lugar a partir do qual ele estabelece relações com outros sujeitos. Essas relações constituem um campo de forças entre quereres e é dentro dele que o sujeito manobra em prol de seus objetivos. $\mathrm{O}$ cálculo só se estabelece, então, a partir da definição de um "próprio" em meio a um conjunto de alteridades e/ou exterioridades.

Além disso, o estabelecimento de um "próprio" significa uma "vitória do lugar sobre o tempo", ${ }^{12}$ pois "permite capitalizar vantagens conquistadas, preparar expansões futuras e obter assim para si uma independência em relação à variabilidade das circunstâncias"; ${ }^{13}$ ou seja, o tempo estaria de algum modo "controlado" através da fundação de um "lugar autônomo". É como se o sujeito estivesse num patamar fora da movimentação da vida, um refúgio, e que exatamente por estar fora lhe permitiria uma pausa sobre os eventos e um olhar diferenciado; um lugar para repor as energias, refletindo sobre o vivido porque distante dele.

Dentro do quadro apresentado, acredito que a prática da escrita possa funcionar como a construção de um "próprio", como o citado "lugar autônomo". Estar diante da folha em branco e cingi-la de tinta seria um gesto imemorial que dissolveria diferenças e, como tal, se constituiria como um refúgio das oscilações do mundo - refúgio a que sempre se retornaria na escritura e na leitura, como elementos disponíveis a se criar um certo distanciamento. O gesto de escrever e o papel escrito definiriam, assim, uma vitória do lugar sobre o

${ }^{11}$ Seguindo De Certeau - "A estratégia postula um lugar suscetível de ser circunscrito como algo próprio e ser a base de onde se podem gerir as relações com uma exterioridade de alvos ou ameaças" -, o que proponho aqui é pensar as cartas como um próprio que pode gerenciar as tomadas de decisão dos jesuítas em termos individuais - como experiência devocional - e coletivos - como sedimentação da Ordem na sociedade. Cf. Michel de Certeau, A invenção do cotidiano. Artes de fazer, Petrópolis, Vozes, 1994, p. 99.

${ }^{12}$ A invenção do cotidiano, p. 99.

${ }^{13}$ Idem, ibidem. 
tempo, uma escansão que permite um afastamento. Um lugar para onde se pode ir e de onde se pode ver o movimento do mundo com outros olhos.

Definir a escrita como um "lugar", então, gera um distanciamento que constrói uma visão sobre as coisas fora dela. É assumir a ideia de um patamar que viabiliza uma vista de tudo que foi alocado como fora daquele "próprio". E é assim que a estratégia se torna possível, pois o cálculo, a reflexão sobre o campo de forças exige leituras sobre as exterioridades, e a criação de um lugar próprio permite exatamente isso.

$\mathrm{Na}$ verdade, ao se instituir essa dimensão espacial, se permite a elaboração de um conhecimento, pois o distanciamento constrói um entendimento: ele organiza o que vê. E organizar representa uma autoatribuição de poder: "eu organizo" significa dizer que as exterioridades seguem meus critérios interpretativos. É exibir o "poder do saber" que se instaura através desse privilégio do lugar, ${ }^{14}$ "fora do tempo", "fora da história".

Compreender a escrita como estratégia é defini-la como espaço de manipulação de relações de forças e, no caso da Companhia, acredito que possamos afirmá-lo tanto num âmbito individual como num coletivo. A estratégia individual estaria referida ao campo de forças espiritual, aos caminhos da ascese, enquanto a estratégia coletiva se realizaria na demarcação de um lugar social, no quadro das tensões e transformações religiosas e políticas do século XVI. Escrever, assim, poderia ser o lugar para uma renovação e/ou recuperação da fé, o lugar para transformar as incertezas em devoção ou, ainda, o lugar de afirmação de uma pertinência e/ou necessidade social, o lugar para transformar os impasses cotidianos em soluções.

Inácio de Loyola funda os alicerces da Companhia em dois textos, os Exercícios Espirituais e as Constituições; e aqui destaco a peculiaridade de serem textos, de terem sido escritos num dado momento e se tornarem suporte escriturário para as ações empreendidas pelos jesuítas. Como O’Malley afirma, os jesuítas eram "primeiro e primeiramente ministros da palavra", ${ }^{15}$ a qual compreendiam de modo amplo, tanto como marca de seu ofício, na pregação e no ensino, quanto como a própria presença divina. Os Exercícios materializam a ideia.

Antes de tudo, “por mais 'espirituais' que sejam, os Exercícios de Inácio fundamentam-se numa escritura". ${ }^{16}$ A sistematização de uma prática de teofa-

\footnotetext{
${ }^{14}$ Idem, p. 100.

${ }^{15}$ Op.cit., p. 145.

${ }^{16}$ Roland Barthes, Sade, Fourier, Loyola, São Paulo, Martins Fontes, 2005, p. 37.
} 
nia não necessariamente exigiria a redação, podendo perpetuar-se como prática estrito senso; entretanto, ela se registra na palavra escrita. Mas não só.

Como propõe Barthes, os Exercícios inauguram uma finalidade: a interlocução com Deus. Segundo ele, a meditação religiosa submetida a um trabalho metódico visando uma união com Deus já existia; porém, o esforço de Inácio propõe "uma língua nova que possa circular entre Deus e o exercitante" ${ }_{17}^{17}$ uma língua através da qual o exercitante possa indagar coisas, o que o faz equivaler os Exercícios a uma mântica, uma arte de consulta divina, pois compreenderia a pergunta dirigida pelo homem à divindade e a resposta devolvida pela divindade; ${ }^{18}$ ou seja, além de seres escritos, os Exercícios são uma língua que buscam a palavra divina.

Entretanto, para mim, os Exercícios podem mais do que dar corpo a esse valor à palavra; podem também exibir a ideia da escrita como uma estratégia devocional. Ao ser redigido, aquele conjunto de práticas proposto por Inácio instaura um "próprio", um "lugar" para o qual os noviços devem seguir para garantir os recursos interiores exigidos por um compromisso vitalício. Os Exercícios "ofereciam princípios claros porém flexíveis para a sua própria jornada espiritual". ${ }^{19}$

É verdade que se o considerarmos exclusivamente como uma sistematização de práticas e, nesse ponto, prescindindo de uma escrita, a estratégia devocional se instauraria também a despeito dela. Entretanto, não creio que possamos afastar-nos da circunstância material antes aludida: os Exercícios, "por mais 'espirituais' que sejam, fundamentam-se numa escritura”. Tal assertiva se constitui não apenas pelo fato de terem sido escritos por Inácio e através da sua redação, compartilhados - eles existem porque são escritos -, mas também pela originalidade da proposta de interlocução divina; ou seja, por podermos compreender as práticas como uma nova "língua", capaz de instituir o diálogo entre o exercitante e Deus. Desse modo, creio que possamos associar a redação de Inácio - a construção dos Exercícios - ao exercício do exercitante, pois, em sua prática, ele "falaria" ou "escreveria" à divindade.

Para mim, a redação de Inácio e a ação do exercitante devem ser entendidas como estratégias devocionais. São estratégias porque, nas duas circunstâncias, acaba por se instituir um "lugar" do qual se escapa à transitoriedade para melhor percebê-la, já que esse escape tem em vista um contato direto com

\footnotetext{
${ }^{17}$ Idem, p. 42.

${ }^{18}$ Idem, p. 44.

${ }^{19}$ John O’Malley, op. cit., p. 64.
} 
o divino. No caso do exercitante, a meta é ouvir a Deus através da escolha, ${ }^{20}$ ao que, depois, o exercitante retorna ao transitório e contingente. No caso de Inácio, a meta é o compartilhamento de sua experiência, a possibilidade de atualizar uma sua teofania a despeito das contingências, mas para as quais os religiosos sempre retornam.

Acredito que a dimensão devocional do exercitante seja evidente pela conexão que estabelece com o divino e pela motivação de fé que tal conexão possa efetuar numa vida religiosa. Cabe, entretanto, algumas linhas sobre a escrita de Inácio como devoção.

Ao escrever, Inácio permite que sua experiência/interpretação particular seja fixada e, como tal, universalizada. Como afirma De Certeau, a escrita é um instrumento capaz de reter as coisas e de se estender nas distâncias. ${ }^{21}$ Seu poder de estocar dados e avançar em destinatários a faz uma força de continuidade, um elemento capaz de atravessar o tempo. Esse "atravessar", em nosso caso, representa uma suspensão do tempo que, por lançar o leitor a um "lugar", restabelece, na diversidade dos religiosos, a experiência do próprio Inácio. A redação dos Exercícios instaura um atemporal que reúne todos os jesuítas.

Se a nomeação de estratégia pode estar ratificada na redação de Inácio, é preciso dar ênfase à sua dimensão devocional. Uma das características que diferencia a Companhia de Jesus das outras ordens religiosas no século XVI é o pressuposto básico de uma dimensão social que deve ser cumprida, num desejo de inserção em realidades profanas para santificá-las. ${ }^{22}$ Se outras ordens religiosas possuem uma missão, a assumida pela Companhia é o próprio missionar, o levar adiante a palavra, reunindo o descontínuo formalizado nos infiéis, pagãos e hereges. ${ }^{23}$ Essa interpretação se torna preponderante quando da análise das ações de Inácio e, em especial, da organização da Ordem, pois, desse modo, constituir bases para que terceiros caminhem para a fé compõe o sentido mesmo da vivência cristã. O esforço/sentido da conversão aí encontra seu coração.

\footnotetext{
20 "Os Exercícios foram designados para habilitar a pessoa a fazer tal escolha com objetividade e liberdade de espírito sob a mais imediata inspiração de Deus”. Cf. John O’Malley, op. cit., p. 65.

${ }^{21}$ Michel de Certeau, A escrita da história, p. 217.

${ }^{22}$ Luiz Felipe Baêta Neves, op. cit., p. 27.

${ }^{23}$ Idem, p. 25.
} 
Mas esse pressuposto não se direciona apenas àqueles que estão fora do eixo cristão, servindo inclusive a seus companheiros. Redigir meios de atualizar a sua experiência particular de fé para que outros religiosos pudessem segui-lo seria já um caminho, em si mesmo uma estratégia para consolidar a sua fé. ${ }^{24}$ Segundo John O’Malley, os Exercícios Espirituais incorporavam a essência da conversão espiritual jesuítica, estabelecendo também os paradigmas e as metas de todos os ministérios nos quais a Companhia se engajou; ${ }^{25}$ ou seja, ao redigi-lo Inácio alimentaria a Ordem e esse alimentar satisfaria a si mesmo.

Creio que possamos, pela mesma chave, definir a redação da Fórmula do Instituto, posteriormente consolidada nas Constituições, como também uma estratégia devocional, já que ali se regulava todo o funcionamento da Companhia de Jesus. Segundo O'Malley, “assim como os Exercícios, as Constituições estavam baseadas na pressuposição de que o crescimento psicológico e espiritual ocorrerá e elas providenciavam isso prescrevendo certas coisas como apropriadas aos iniciantes e sugerindo outras como apropriadas aos membros mais amadurecidos". ${ }^{26}$ Deste modo, podemos dizer que a redação das regras jesuíticas é um cálculo em prol do "crescimento espiritual". E como parte fundamental delas, exibindo-se em diversas de suas partes, encontramos a determinação de leitura e redação de cartas.

Segundo as Constituições, as cartas cumpririam função tanto num âmbito individual como coletivo, pois serviriam à "conservação no que toca a alma” e "aumento das virtudes" como também às obrigatórias informação aos superiores e instrução aos subordinados, estabelecendo uma rede entre os religiosos. De acordo com Alcir Pécora,

A presença ostensiva da carta no corpo da Companhia evidencia que sua função está pensada ao menos segundo três aspectos decisivos: o da informação, o da reunião de todos em um e, enfim, o da experiência mistica ou devocional. ${ }^{27}$

Neste momento, enfatizo a experiência mística. Considero, como Pécora, que as cartas assumem um papel de atualização da missão e da palavra divina, estabelecendo-se como vértice que liga o humano ao sagrado, como uma linha que, vinda diretamente do Alto, toca o humano, transformando-o. ${ }^{28}$

\footnotetext{
24 "Este documento encapsulou a própria essência da conversão espiritual de Inácio e a apresentou de uma forma intencionada a guiar outras mudanças análogas de visão e motivação". Cf. John O'Malley, op. cit., p. 20.

${ }^{25}$ Idem, ibidem.

${ }^{26}$ Op. cit., p. 516.

${ }^{27}$ Alcir Pécora, op. cit., p. 381.

${ }^{28}$ Luiz Felipe Baêta Neves, op. cit., p. 29.
} 
Haveria uma analogia entre a escrita humana e as divinas escrituras, qualificando as cartas: mais do que informar, as palavras missionárias deveriam incendiar "escritor e leitor numa mesma febre de fé", irmanando-os na experiência devocional. ${ }^{29}$ Por tal sentido é que o editor das cartas de Inácio de Loyola comentaria que a leitura delas produzia “...'gozo e alegria' incontáveis, deixando os 'irmãos banhados em alegria de ouvir', em que mesmo 'uma só palavra os consola tanto'. No sentido contrário, alguma demora nas cartas de santo Inácio é tomada pelos irmãos como 'um castigo', em que eram privados 'do leite da consolação costumeira"' ${ }^{30}$

Se, de modo genérico, não podemos descurar que, assumindo um papel na experiência mística dos religiosos, a escrita de cartas poderia ser uma emulação ascética, no caso específico da Narrativa Epistolar de Cardim isso deve ser considerado.

Charlotte Castelnau-L'Estoile ${ }^{31}$ nomeou um conjunto de textos da literatura jesuítica como "narrativas de consolação", onde a consolação corresponderia à manifestação de alegria por se assistir à efetivação da vontade de Deus. Ela interpreta que as informações construídas em tais textos - especialmente nas cartas - não se sedimentam exclusivamente numa verdade de fatos, mas também numa verdade mística. Castelnau-L'Estoile nomeia os jesuítas de "trabalhadores de uma vinha estéril", destacando a percepção construída entre os agentes acerca de sua atuação: o trabalho da conversão entre nativos do Brasil conquista especial valor na dificuldade que apresenta e, como corolário, a consolação se realiza em mesma medida.

E, exatamente em tal interpretação, a Narrativa Epistolar revela-se como "narrativa de consolação", pois, ao registrar as informações da viagem sobre a Missão do Brasil, Cardim articula a exibição de realidades, de experiências com a produção de um discurso capaz de incendiar a fé entre os religiosos e impulsionar a missão em si mesma.

As primeiras palavras de Cardim na Narrativa:

Nesta com o favor divino darei conta a Vossa Reverência da nossa viagem e missão a esta província do Brasil, e determino contar todo o principal que nos tem sucedido, não somente na viagem, mas também em todo o tempo da visita que Vossa Reverência tenha maior conhecimento das coisas desta província, e

\footnotetext{
${ }^{29}$ Alcir Pécora, op. cit., p. 382.

${ }^{30}$ Idem, ibidem.

${ }^{31}$ Les ouvriers d'une vigne stérile: lês jésuites et la conversion des indiens au Brésil, 1580 - 1620, Lisboa , Fundação Calouste Gulbenkian, 2000.
} 
para maior consolação minha, porque em tudo desejo de comunicar-me com Vossa Reverência e mais padres e irmãos desta província. ${ }^{32}$

Nas intenções da carta, já aparece o propósito de dizer das experiências casado a um regozijo devocional, mas no conjunto do texto encontramos inúmeras referências à consolação das práticas, a alegria de viver o que se vive como aquele que encontra seu lugar. Assim é que depois da primeira descrição dos recebimentos indígenas, escreve: "Dali fomos à aldeia de São João, duas léguas desta, onde houve semelhantes recebimentos e festas, com muita consolação dos índios e nossa". ${ }^{33}$

Segundo Cardim, os índios se alegrariam com a chegada dos jesuítas porque estariam vivendo, de certo modo, o encontro do Caminho; já os religiosos, por verem e acreditarem no resultado de seu esforço catequético. De um modo ou de outro, a alegria de cumprir a vontade divina.

Assim também entre colonos:

No dia do Anjo preguei na matriz da vila: houve muitas confissões, e comunhões, com extraordinária consolação do povo por haver dias que não ouviam missa, por estar seu vigário suspenso: dos moradores portugueses e índios fomos bem agasalhados, com grandes sinais de amor e abundância do necessário. ${ }^{34}$

Os que liam ou escutavam as palavras de Cardim imaginavam a nature$\mathrm{za}$ - como os frescos bosques baianos com que abri o texto -, os personagens ou o cotidiano vivido no Brasil sempre inspirados pelas certezas da fé, numa exibição contínua das transformações que ela era capaz de fazer e dos jesuítas como os agentes da transformação. Em resumo: "a identidade missionária e a legitimação de seu projeto catequético se constroem coladas à elaboração da própria narrativa". ${ }^{35}$

A redação de cartas, assim, se constitui como um "modo de proceder" jesuítico, pois dava forma ao estilo de vida e ministério dos jesuítas. A expressão "nosso modo de proceder" fora proposta por Inácio e definia o ethos institucional da Ordem; ou seja, definia-lhes uma identidade para si e frente aos outros: "Seus membros acreditavam que a adoção de um mesmo 'modo

\footnotetext{
${ }^{32}$ Fernão Cardim, Narrativa Epistolar, p. 141.

${ }^{33}$ Idem, p. 146.

${ }^{34}$ Idem, p. 148.

${ }^{35}$ Cristina Pompa, Religião como tradução. Missionários, Tupi e Tapuia no Brasil colonial, São Paulo, Edusc, 2003, p. 20.
} 
de proceder' era o que os fazia 'jesuítas”" ${ }^{36}$ Sendo assim, seja por permitirem um exercício devocional na escritura, consolidando individualmente o "ser jesuíta", seja por viabilizarem a comunicação entre religiosos, concretizando uma identidade coletiva, as cartas podem ser referidas como parte do "modo de proceder" da Companhia.

\section{Estratégia coletiva}

A Companhia de Jesus fora fundada num ideal de propagação da fé, caracterizando-se como uma ordem missionária quando o modelo monacal ainda era hegemônico. O sopro dos acontecimentos entre fins do século XV e início do XVI certamente foi responsável pelas experiências e escolhas de Inácio de Loyola, fazendo residir no alicerce da ordem o projeto da conversão: os novos mundos conquistados com suas gentes pagãs e o cisma da Igreja Católica seguramente foram estímulos em seu desejo de evangelização.

O ideal missionário exige um pressuposto primário: o entendimento de que a humanidade é uma unidade que, por circunstâncias, está desconectada. ${ }^{37}$ O descontínuo aparece, então, como urgência de reunião e é dessa urgência que o projeto catequético se alimenta. A propagação da fé se realiza em nome da conversão do outro em algo de mesmo, a eliminação da diferença como o caminho para a unidade perdida.

Mas essa propagação e conversão só possuem sentido e só se realizam no mundano, exigindo, pois, dos "trabalhadores pela unidade" que se comprometam com uma dimensão social. Os inacianos não esperam que o mundo se desloque em direção à religião, mas, através deles, que a religião se desloque em direção ao mundo: eles serão a ponte que levará o divino ao profano. Segundo a Fórmula do Instituto, o documento fundador da ordem, os jesuítas seriam:

(...) obrigados a cumprir, sem delongas, e na medida de nossas forças, quanto nos ordenar o Romano Pontífice e os que pelo tempo adiante lhe sucederem, para proveito das almas e propagação da fé, seja quais forem as províncias a que nos enviar, quer nos mande para os turcos, quer para as terras de outros infiéis, ainda para as partes que chamam da Índia, como também para os países de hereges ou cismáticos ou quaisquer nações de fiéis. ${ }^{38}$

\footnotetext{
${ }^{36}$ José Eisenberg, op. cit., p. 32.

${ }^{37}$ Luiz Felipe Baêta Neves, op. cit., p. 25.

${ }^{38}$ Apud Serafim Leite, História da Companhia de Jesus no Brasil, Lisboa/Rio de Janeiro, Portugália/Civilização Brasileira, 10 volumes, 1938, tomo I, p. 7.
} 
E o que imediatamente se faz necessário para a realização desse intento? Sair da Europa, seguir destinos desconhecidos, indo ao encontro das gentes que demandavam os cuidados da cristianização. Acredita-se que o sagrado seja contagioso - é o que os faz certos da conversão -, mas o profano, no contato, pode apoderar-se dele e acabar degradando-o. ${ }^{39}$ Surgem, assim, enormes riscos para aqueles que se propõem imiscuir-se ao mundano. Os missionários viverão de perto o risco de serem aviltados pelo profano, já que estavam mergulhados nas alteridades e diferenças que procuravam transformar em mesmo.

Regramento, disciplina, rigor. O “modo de proceder" jesuítico seria ferramenta fundamental nesse processo, pois através dele seria possível uma atualização dos preceitos cristãos diante das novas realidades. Exemplo ímpar dessa conduta está nos Exercícios Espirituais. A cada nova contingência ou dúvida, os jesuítas dispõem de um instrumento a que podem recorrer para se realimentarem do sagrado - a palavra divina - e para garantirem uma sacralidade nas escolhas sociais.

A formalização de mecanismos reguladores e afirmadores do sagrado os Exercícios, as Constituições, os padres visitadores - exibia originalidade na Companhia de Jesus, distinguindo-a das outras ordens.$^{40}$ A sistematização em si mesma apresentava-se já como um "modo de proceder":

Em contraste com os dominicanos, cuja organização confederativa era estruturada sobre normas e obediência cega aos superiores da ordem, a ordem jesuítica tinha uma longa e detalhada lista de normas, que supostamente permitia a seus membros, dispersos pelo mundo, agir sem ter que esperar pela chegada de ordens provindas de superiores na Europa. ${ }^{41}$

A abertura ao particular vivido por cada jesuíta era possível pela infraestrutura que as normas lhes forneciam. Elas garantiam uma identidade entre os religiosos que, embora vivendo realidades distintas, eram insuflados por mesmos princípios ou práticas. ${ }^{42}$

Essa comunhão entre normas e religiosos era o que instituía o "modo de proceder", permitindo o enfrentamento de uma realidade exterior e/ou

\footnotetext{
${ }^{39}$ Roger Caillois, O homem e o sagrado, Lisboa, Edições 70, 1988, p. 23.

40 "Apesar de dominicanos, teatinos, capuchinhos e franciscanos terem todos produzido documentos intitulados 'Constituições', esses textos não continham os detalhados aspectos de organização institucional das Constituições jesuíticas.” Cf. José Eisenberg, op. cit., p. 44.

${ }^{41}$ Idem, p. 45.

${ }^{42}$ Como, por exemplo, o estudo e uso de línguas nativas como estratégia de aproximação para conversão em missões da Ásia, África ou América.
} 
estranha com vistas a seu enquadramento aos parâmetros jesuíticos. ${ }^{43}$ Sendo assim, através dele se realizava o projeto de conectar o profano ao sagrado, de estabelecer a continuidade divina onde ela havia sido desconectada.

Uma peculiaridade do "modo de proceder" é sua abertura à experiência diacrônica, ao enfrentamento cotidiano dos desconhecidos que a missionação proporcionava. Seu valor está na manutenção de uma tensão entre a permanência, o cumprimento das regras da Companhia, e a mudança, as realidades múltiplas das quais o jesuíta não escapa. Sendo ação de homens, ele funciona como uma atualização permanente daquilo que se crê. Tal característica de atualização conferia uma singularidade que publicamente definia uma imagem para a Companhia e, a meu critério, a insere em parâmetros da modernidade.

Uma das ações que compõe esse "modo de proceder" e que configura a modernidade da atualização é justamente a escrita de cartas. Em sua preocupação em definir mecanismos de controle e retidão para aqueles que gostariam de seguir seus princípios, Inácio de Loyola determina como eixo central nas Constituições a escrita e a leitura de cartas. Seja como estratégia formativa de noviços, como instrumento de administração interna ou ainda de comunicação entre os membros, as cartas materializavam a originalidade da Companhia; afinal, através delas se poderia de fato erigir uma identidade coletiva: "era através delas - a todos que as liam ou ouviam - que se comunicava o que era ser um jesuíta e como o 'modo de proceder' era posto em prática ao redor do globo". ${ }_{4}$

Representando "uma inovação nas técnicas de administração institucional, vigentes no século XVI" ${ }^{45}$ as cartas foram elemento primordial da sistematização jesuítica, destacando-se como componentes do "modo de proceder". A centralidade delas nas práticas missionárias da Companhia já foi inúmeras vezes assinalada, sendo apresentada como "espinha dorsal"46 ou como a "verdadeira chave de todo o seu sistema". ${ }^{47}$

Para os missionários, aquela era a única via de comunicação com pessoas que tinham algum interesse em suas atividades pastorais. As cartas que chegavam da Europa, por sua vez, não raro causavam comoção no Brasil; assim também

43 "Algumas vezes, os jesuítas falavam de seu 'Instituto' e entendiam por isso o modo segundo o qual viviam e trabalhavam, e incluíam no termo todos os documentos oficiais da ordem, especialmente a Fórmula e as Constituiçoes." Cf. John O'Malley, op. cit., p. 24.

${ }^{44}$ John O'Malley, op. cit., p. 29.

${ }^{45}$ José Eisenberg, op. cit., p. 57.

${ }^{46}$ Idem, p. 49.

${ }^{47}$ Cristina Pompa, p. 81. 
longos períodos sem notícias eram causa de desconsolo e frustração entre irmãos. A chegada de uma carta jesuítica era seguida de sua leitura em voz alta para todos os irmãos. Essas sessões de leitura constituíam ocasiões especiais na vida dos missionários na colônia, às vezes durando toda a madrugada. ${ }^{48}$

Realizar a evangelização a despeito das dificuldades conferia aos jesuítas seu próprio sentido de ser, as palavras consolavam porque reafirmavam as escolhas que os tornaram jesuítas. Mas se a epistolografia jesuítica foi vista antes como estratégia devocional - como a construção de um próprio através do qual o religioso poderia encaminhar-se ao divino -, ela também deve ser vista como a construção de um próprio que é coletivo.

Por meio das informações contidas nas cartas os inacianos consolidavam seus laços e garantiam um sentido de unidade diante das ameaças advindas do "ir ao encontro de turcos, infiéis e hereges", pois a fragmentação no espaço se unia ao contato com alteridades. Porém, além de um sentido de unidade, sobretudo para o argumento aqui desenvolvido, as informações alimentavam de experiências uns aos outros. A leitura ou audição da carta construía um conjunto de dados comum a todos os religiosos do qual passavam a poder dispor em suas trajetórias individuais. No caso da Narrativa Epistolar podemos pensar, por exemplo, que os dados sobre uma saudação entre os Tupi, como a que recebeu Cardim e Cristóvão de Gouvêa no Espírito Santo, evitariam interpretações apressadas sobre a encenação de sequestro e cativeiro do padre visitador logo após a comitiva ter sido rodeada por vinte canoas cheias de índios lançando flechas ao modo de "guerra naval". 49

A escrita, assim, é um saber que qualifica os envolvidos na empresa missionária e que, exatamente por isso, permite a elaboração de cálculos em prol da propagação da fé. Como afirmado por Eisenberg: a "supervisão constante da atividade dos irmãos permitia, por um lado, que os superiores avaliassem o êxito das missões e planejassem sua organização e expansão". ${ }^{50}$ Quando, por exemplo, Cardim assinala que é "grande injúria" não aceitar os presentes que os índios dão, ele registra a sua experiência particular, mas também mapeia ações futuras para outros missionários.

No âmbito individual, a escrita poderia delinear-se como um caminho de ascese por se fazer um lugar onde se processava a transformação de incertezas em elementos legíveis e, portanto, onde se processava um domínio sobre a

\footnotetext{
${ }^{48}$ José Eisenberg, op. cit., p. 49.

${ }^{49}$ Fernão Cardim, Narrativa Epistolar, p. 166.

${ }^{50}$ Idem, p. 57.
} 
circunstância. No âmbito coletivo, como saber qualificado, ela pode ser vista como o estabelecimento de um próprio que configura a identidade jesuítica e permite as articulações desta identidade social com outras, especialmente aquelas envolvidas no processo colonizador.

Se estratégia é a manipulação dentro de um campo de forças é preciso considerar que a identidade coletiva pode se tornar um poder. O sentido de unidade da Companhia interage diretamente no campo de forças composto por outros sujeitos de querer: os jesuítas podem parecer junto às Coroas ibéricas como os mais adequados religiosos para a catequese além-mar e ganharem delas prerrogativas e privilégios não-concedidos a outras ordens religiosas.

As cartas, assim, são ferramentas preciosas para que a Companhia se entenda como ordem religiosa e que conquiste espaços sociais e legitimidade em seu propósito de propagação da fé. A difusão dos resultados da catequese para o mundo externo incentivava vocações - onde o alistamento deve ser compreendido como sedimentação da Ordem -, mas conquistava também um reconhecimento "daqueles que lhes prestavam ajuda político e financeira: o papado e os reis católicos europeus". ${ }^{51}$

Todos os das aldeias, grandes e pequenos, ouvem missa muito cedo cada dia antes de irem a seus serviços, e antes ou depois da missa lhes ensinam as orações em português e na língua, e à tarde são instruídos no diálogo da fé, confissão e comunhão. Alguns assim homens como mulheres, mais ladinos, rezam o rosário de Nossa Senhora; confessam-se a miúdo; honram-se muito de chegarem a comungar, e por isso fazem extremos, até deixar seus vinhos a que são muito dados, e é a obra mais heroica que podem fazer; quando os incitam a fazer algum pecado de vingança ou de desonestidade, etc. respondem que são de comunhão, que não hão de fazer a tal coisa. ${ }^{52}$

Quando Cardim escreve tais palavras ele não exibe apenas para os noviços que os esforços jesuíticos valem à pena: a ascendência religiosa sobre os indígenas, ou melhor, a apresentação dela cria expectativas para o controle régio ou mesmo para os interesses de colonos. Foram os jesuítas que organizaram os aldeamentos e eram eles que se responsabilizavam por esse ordenamento na vida cotidiana dos nativos. As cartas são veículo de promoção e, como tais, dão sustentação a um próprio para a Companhia.

Na publicização - coletivização da experiência e das percepções - se estabelece uma coerência interna que demarca identidades sociais frente a

${ }^{51}$ Idem, p. 50.

${ }^{52}$ Fernão Cardim, Narrativa Epistolar, p. 156. 
outras ordens e define forças na efetivação de alianças. Desta maneira é que a escrita de cartas pode ser vista também como uma estratégia coletiva.

\section{A carta de Cardim: a missão e a colonização através do outro indígena}

A Narrativa Epistolar é uma carta dirigida ao Provincial em Portugal. Imediatamente reconhecemos a obediência à "sétima parte principal" das Constituições, onde se determina que o missionário mantenha informado o superior por carta, lembrando que seria através das informações ali contidas que uma reflexão e um cálculo para as ações futuras poderiam ser realizados. É importante dizer que se determina também que o superior escreva para o missionário, instruindo-lhe sobre como proceder para alcançar o fim desejado, o que revela a consciência dos agentes na escrita como estratégia. A carta de Cardim tem outro destino certo além do próprio superior, pois sua leitura junto aos irmãos era ação esperada. A Narrativa cumpre, então, o papel de meio informativo e formativo junto à Companhia.

Não podemos ver a carta como algo espontâneo; ela se realiza sob exigência, tornando-se exemplo do que foi dito até aqui. Ao escrever seguindo os ditames, Cardim garantia a articulação de vínculos coletivos, e, ao manifestar sua "consolação", dá evidência de que a escrita concedia solidez à sua fé.

É importante lembrar que os vínculos coletivos que a carta poderia proporcionar eram acionados dentro de um quadro social que passava por profundas transformações que afetavam diretamente a religiosidade e a religião católica, como a secularização e a Reforma, e estavam conectadas à constituição de uma nova dinâmica mundial, através da expansão marítima e comercial e dos processos colonizadores.

O Provincial para o qual escreve está sediado em Portugal e foi de lá que os primeiros missionários partiram, num acordo estabelecido com El-Rei D. João III. Tais referências mostram de perto os vínculos sociais que a Ordem determinava para si: a união com a Coroa que mais se expandira até aquele momento e que, como consequência, entrara em contato com diferentes povos, não era gratuita.

Creio, então, que devamos avaliar a Narrativa com uma chave dupla que abre as portas tanto da experiência mística como aquela voltada ao mundano, que, em nosso caso, refere-se à experiência colonizadora da América portuguesa.

A porta que se abre ao mundano pode ser vista no primeiro parágrafo de Cardim, onde diz pretender escrever da viagem e missão à província do Brasil, 
determinando-se a contar da viagem e do tempo ali vivido para que o superior soubesse das coisas da província. Três coisas me chamam a atenção.

A primeira é a nomeação do Brasil como Província. Tomando emprestado o modelo dominicano, os jesuítas definiram a Província como a unidade administrativa básica da Companhia, e a Missão do Brasil se transformou em Província autônoma em 1553, sob a égide de Manuel da Nóbrega. A referência, então, alude a uma configuração religiosa do espaço, definindo as áreas de atuação da Ordem.

Acredito que as circunscrições espaciais não sejam elementos naturais, mas sim representações derivadas de uma manipulação simbólica que classifica e divide, criando limites de acordo com interesses históricos. ${ }^{53} \mathrm{Na}$ criação de uma circunscrição espacial se constroem simultaneamente percepções de identidade e de alteridade, onde a primeira reúne aqueles que se inscrevem dentro dos limites traçados e a segunda é definida para todos que estão fora dos mesmos.

Sendo assim, a definição do destino ser uma Província jesuítica revela a apropriação que aqueles religiosos já haviam feito da América portuguesa. $\mathrm{O}$ discurso expõe o porquê de estar no Brasil: realizar a missão. A transformação da humanidade para a concretização da unidade católica implicava na transformação de espaços. As Províncias podem ser os fios que tecem essa união.

Entretanto, essa transformação de humanidades e espaços acaba cumprindo também papel importante junto a outros interesses. A ocupação, significação e transformação do espaço e de suas gentes eram medidas imperativas à colonização. Agindo em nome da missão, os jesuítas terminavam por trabalhar também em nome da Coroa portuguesa.

O segundo ponto que me chamou a atenção no parágrafo foi a distinção entre viagem e missão. A viagem não estaria de algum modo contida na missão? Da Fórmula do Instituto à designação específica de Cristóvão de Gouveia para atuar como visitador, viagem e missão não fariam parte de uma mesma realidade? O que poderia estar sendo indicado com esta distinção?

De um modo genérico é certo que viagem e missão eram faces de uma só moeda, pois chegar a "turcos, infiéis e hereges" demandava o viajar. Porém, participar de uma viagem não representava necessariamente estar já dando conta da missão de que se foi incumbido. Imagino que Cardim desejasse distinguir as ações empreendidas pelos religiosos num deslocamento genérico daquelas que se enraizaram na singularidade missionária, pois não podemos ${ }^{53}$ Pierre Bourdieu, O poder simbólico, Lisboa, Difel, 1989, p. 112-113. 
esquecer que entre chineses, japoneses ou brasis as missões ganhavam especificidades.

Os religiosos exercitaram seus "ministérios com os da nau, confessando, pregando, pondo em paz os discordes, impedindo juramentos e outras ofensas de Deus, que em semelhantes viagens se cometem todos os dias", 54 além de cuidarem dos muitos que caíram doentes. Eles garantiram que os cristãos não se desapegassem da fé diante das intempéries. Entretanto, a mobilização da viagem não se fazia em nome deles. A comitiva de Cristóvão de Gouveia se formara para atender aos religiosos que atuavam junto aos índios. O visitador deveria garantir que fossem capazes de empreender a conversão junto àqueles que se apresentavam como alteridade na América portuguesa. É a América, ou melhor, o Brasil que condiciona a distinção entre viagem e missão.

Conhecer as "coisas do Brasil", assim, se torna central. Escreve-se para que o superior tenha ciência desse "tempo vivido", das experiências e, a partir delas, possa conduzir as medidas futuras. As "coisas do Brasil" exibem a abertura de porta ao mundano, mas também definem previamente um sentido aos índios: eles são o particular, o diferente, a alteridade. Eles são os outros que devem ser reunidos na unidade católica.

Vale uma observação: a escrita como estratégia pessoal e coletiva passa pela criação de alteridades. Na experiência mística encontramos a ideia de progresso individual, de gradativa santificação, o que remete ao estágio anterior uma alteridade: eu já sou outro através da fé. Na experiência coletiva, instauram-se também clivagens por contrastes, onde o "modo de proceder" diferencia jesuítas de outros religiosos, ou, mais especialmente no caso dos índios, entre os que escrevem e os que não escrevem. Na construção desses outros reside o sentido missionário. Devemos ainda considerar que, para os jesuítas, a experiência mística se realizava através de obras, ou seja, a experiência da catequese transformava o outro indígena ao mesmo tempo em que transformava o próprio jesuíta. A escrita sobre o outro, então, ao cumprir uma emulação devocional, indica previamente um papel ao nativo, tornando-o elemento da progressão da fé do próprio missionário.

O discurso de alteridade é caminho para a realização daquilo que se acredita, pois é do descontínuo que o missionário faz sua vida. Como resultado,

${ }^{54}$ Fernão Cardim, Narrativa Epistolar, p. 142. 
a escrita sobre o outro revela muito de $s{ }^{55}$ Ler ou interpretar as qualificações sobre os índios, assim, diz dos missionários.

Moravam os índios antes de sua conversão em aldeias, em umas ocas, ou casas muito compridas (...). Cada casa destas tem dois ou três buracos sem portas nem fecho: dentro delas vivem logo cento ou duzentas pessoas, cada casal em seu rancho, sem repartimento nenhum, e moram duma parte e outra, ficando grande largura pelo meio, e todos ficam como em comunidade, e entrando na casa se vê quanto nela está, porque estão todos à vista uns dos outros, sem repartimento ou divisão. ${ }^{56}$

A descrição sobre as ocas se estende em outras características, mas a qualificação pela falta já é visível. As ocas não têm portas ou fecho, não possuem repartimento ou divisão. A ausência expõe o modelo que conduz à comparação e que podemos ter acesso na própria carta, nos detalhes sobre os Colégios da Companhia:

Os padres têm aqui colégio novo quase acabado, é uma quadra formosa com boa capela, livraria, e alguns trinta cubículos, os mais deles têm janelas para o mar. O edifício é todo de pedra e cal de ostra, que é tão boa como a pedra de Portugal. Os cubículos são grandes, os portais de pedra, as portas d'angelim, forradas de cedro... ${ }^{57}$

A completude e beleza do Colégio da Bahia se inscrevem em compartimentos e portas. Portas e janelas que não são buracos, mas portais que podem se abrir para o mar. O que falta neles é o que temos e nossa ação catequética pode fazê-los viver a nossa vida, pois moravam nas ocas antes da conversão. Transformados pela catequese transformam também sua moradia, ao menos é a intenção do discurso. Assim, o discurso da falta cria uma imagem de outro ao mesmo tempo em que materializa um lugar para a ação jesuítica.

"As terras são muito boas, estão por cultivar, por serem infestadas de Guaimurés, gentio silvestre, tão bárbaro que vive com brutos animais nos matos, sem povoação, nem casas...”. ${ }^{58}$ Havia aqueles que moravam em ocas e nosso trabalho os transformou. Ainda há índios que sequer ocas têm; vivendo nos matos e sem povoação, apresentam-se como a terra: por cultivar. A cons-

\footnotetext{
${ }_{55}$ Alcir Pécora chega a sugerir que as cartas existiriam não para dizer do outro - ainda que digam e ele seja um elemento axial para que a missão se cumpra -, mas para registrar o "mapa em progresso da própria conversão". Op. cit, p. 373.

${ }^{56}$ Fernão Cardim, Narrativa Epistolar, p. 152.

${ }^{57}$ Idem, p. 144.

${ }^{58}$ Idem, p. 147.
} 
trução da alteridade se faz concomitantemente à criação de uma plataforma de ação.

Mas não encontramos apenas o discurso da falta. Há várias passagens exortativas do comprometimento nativo com os sacramentos.

É muito para ver e louvar Nosso Senhor a grande devoção e fervor que se vê nestes índios quando hão de comungar; porque os homens quase todos se disciplinam à noite antes por espaço de um Miserere, precedendo ladainha e sua exortação espiritual na língua:dão em si cruelmente; nem têm necessidade de esperar pela noite, porque muitos por sua devoção, acabando-se de confessar ainda que seja de dia, se disciplinam na igreja, diante de todos, e quase todos têm disciplina, que sabem fazer muito boas. ${ }^{59}$

Sem considerar possíveis práticas nativas de autoflagelo, os missionários tudo relacionam ao fervor religioso com que os índios se entregam, fazendo da descrição um pilar para a consolação, pois apresentam-na como sucesso da empresa catequética. Mas a confirmação da competência jesuítica é acompanhada de outras qualificações para a alteridade: tem grande devoção de fervor, todos têm disciplina e a fazem muito bem.

As descrições da cultura indígena que integram aquelas cartas dos jesuítas não eram apenas relatos de curiosos espantados com as novidades do Novo Mundo; elas eram também o principal instrumento de justificação de suas práticas missionárias. O uso instrumental da etnografia para fins justificativos fica ainda mais claro na maneira pela qual os jesuítas estrategicamente condenavam os vícios e os maus hábitos dos nativos, quando queriam explicar o fracasso de uma determinada ação, e exortavam suas virtudes e inocência quando queriam demonstrar o sucesso de sua empresa evangélica. ${ }^{60}$

Ao construir imagens sobre a alteridade e sobre as estratégias que lhes deveriam ser correlatas, a epistolografia jesuítica passa a ser instrumento de uma visão que engendra a própria colonização - através do outro se realizará o domínio de si (conquista da fé) e o domínio europeu em solo americano.

\footnotetext{
${ }^{59}$ Idem, p. 151.

${ }^{60}$ José Eisenberg, op. cit., p. 57.
} 